\title{
SENTINEL LYMPH NODE MAPPING IN PATIENTS WITH COLORECTAL CANCER
}

\author{
Ignatov V., N. Kolev, K. Ivanov, A. Tonev, D. Hristov, I. Minev, \\ T. Temelkov, R. Madjov* \\ Department of General and Operative Surgery, *Department of Surgery, University Hospital \\ "St. Marina", Varna, Bulgaria
}

Reviewed by: Assoc. Prof. R. Radev, MD, PhD

\begin{abstract}
BACKGROUND/AIMS: In about $1 / 3$ of the patients with colorectal cancer without metastases which have been radically operated recurrences are observed and these patients die from cancer. This requires improvement of the surgical methods radicality as well as a more accurate determination of the indications for adjuvant chemotherapy administration. The introduction of a method for evaluating the degree of the metastases in colorectal cancer would highlight these issues. To this purpose we apply the method of sentinel mapping. METHODOLOGY: For a period of one year we performed intraoperative sentinel mapping on 103 patients who had been operated for colon or rectal cancer. We used the dying method with Patent Blue V. An algorithm was worked out for sentinel mapping in colorectal cancer. RESULTS: We achieved $100 \%$ performance success and $97 \%$ sensitivity. We increased the volume of the surgical intervention in $100 \%$ of the patients and elevated the clinical stage of $20 \%$ of the patients in Ist and IInd stage by means of ultrastaging with immunohistochemistry. CONCLUSIONS: We conclude that sentinel lymph nodes mapping in colorectal cancer is a diagnostic method which is convenient for the surgeons allowing them for an individualized approach toward each patient.
\end{abstract}

Keywords: colorectal cancer, sentinel lymph node, staging, intraoperative dye mapping, upstaging

\section{INTRODUCTION}

A sentinel lymph node (SLN) is defined as the first lymph node/nodes receiving direct drainage from the tumor (1-7; $9-19 ; 21-27,40,42,43,45)$ and consequently possessing the greatest metastatic potential. $(8-17 ; 20 ; 26,27,40,42,43,45)$ Sentinel mapping in colorectal cancer (CRC) is related to two questions that are important for the surgeon:

1. Is the extending of the lymph dissection necessary in certain patients and which are these patients?

2 . Is the staging of the disease correct?

The most important factor affecting the outcomes of the surgical treatment and the survival rate is the presence of metastases. $\quad(10-13,21,28-38,40,43,45-48,56,57,58) \quad$ The presence of lymph metastases places the patients from $\mathrm{I}^{\mathrm{st}}$ and $\mathrm{II}^{\mathrm{nd}}$ stage into $\mathrm{II}^{\mathrm{rd}}$ stage which significantly deteriorates the prognosis and the survival rate (TNM). (10,12,21,36,39,59) The atypical lymph drainage occurs in about $8-14 \%$ of the patients. $(1,9,10,21,41,44,45)$ The failure to detect it is one of the reasons for the recurrences due to the incorrect staging and adjuvant therapy administration. $(22,45,85)$ It results from specific anatomical features or lymph flow.

The atypical lymph metastases is observed:

- in terms of the localization level of the metastatic lymph nodes (jumping or "skip" metastases)
- in affecting the atypical lymph basin (aberrant lymph drainage) for the given localization of the primary tumor.

In CRC the size of the resection and the lymph dissection are determined by the tumor localization and they have been standardized to a great extent. (96)

The metastatic lymph nodes in the presence of aberrant lymph drainage can be found beyond the limits of the standard lymph dissection size. In these cases the radicality of the surgery requires the extension of the lymph dissection size. $(22,67,73)$ It is important to apply a method for lymph metastases detection. The possibilities of the intraoperative examination and palpation as well as the existing methods for imaging diagnostics of the lymph basin in CRC are not sufficiently reliable. Their sensitivity varies between $20 \%$ and $50 \%$, the lymph nodes are detected with the size over 5 $\mathrm{mm}$, the metastatic potential being determined based on the increased size. (74) According to literary data $50-78 \%$ of the metastatic lymph nodes are sized under $5 \mathrm{~mm}$ $(1,93,97,98)$

This is a reason for the unsatisfactory possibilities of the preoperative and intraoperative diagnostics of the lymph metastases. Lymph mapping with dye visualizes the lymph vessels and the sentinel LN very well in the surgical field even if they are very small in size less than $5 \mathrm{~mm}$ and are otherwise undetectable. $(1,93,97,98)$ 
The direct tumor drainage in the SLN is demonstrated by means of blue stained lymph vessel linking the tumor to the SLN when marked with dye. The visualization of a blue vessel is a guarantee that the "true" SLN will be removed and investigated. (Figure 1-4.)

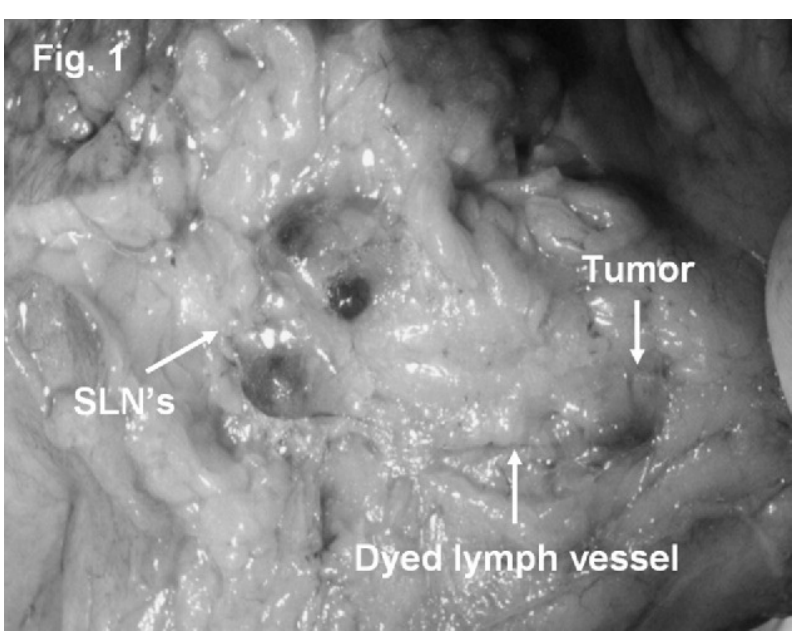

Figure 1. SLN in the mesocolon

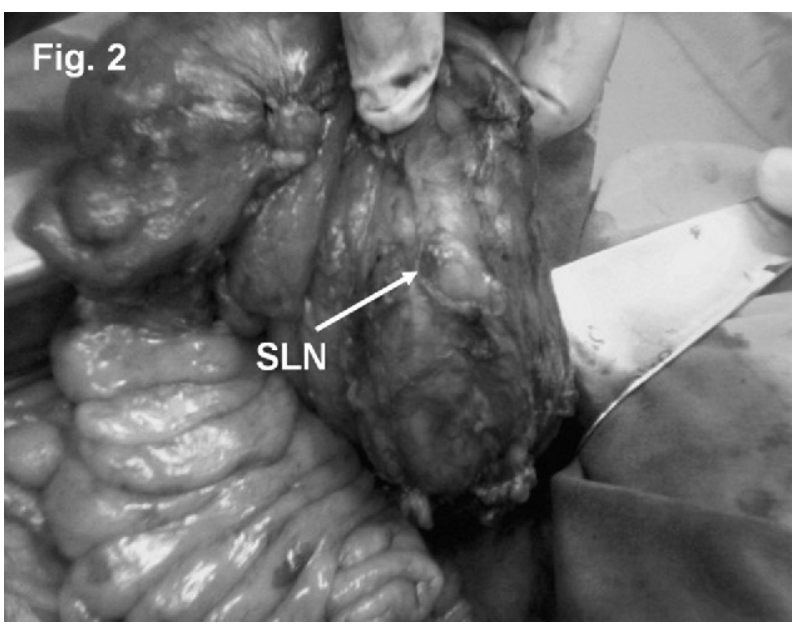

2. SLN in the mesorectum

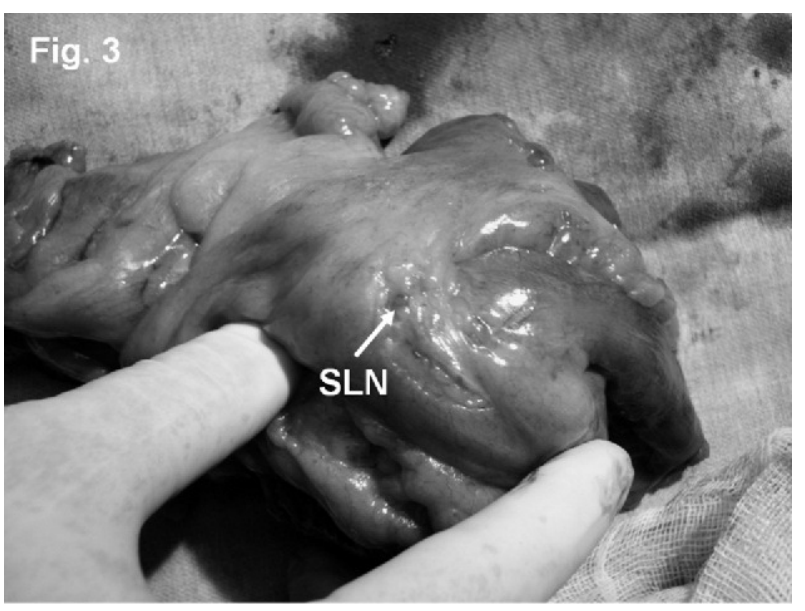

Figure 3. A tiny SLN

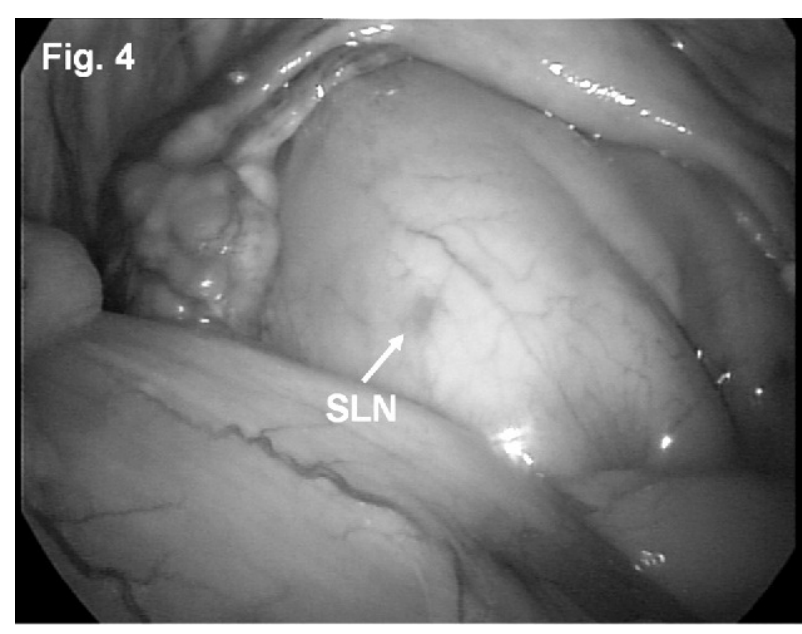

Figure 4. We applied the method of the sentinel mapping in five patients with CRC who had been operated laparoscopically. These patients were not included in this study.

Recurrences are observed in $20-40 \%$ of the operated patients in the Ist and IInd stage. $(85,93,95)$ In half of the patients with recurrences it was established that they were due to metastatic lymph nodes which have not been detected and removed during the surgery.(78-84) For these patients the following was true:

- adequate lymph dissection not performed;

- the disease has not been correctly staged;

- no indications have been given for adjuvant chemotherapy administration $(22,91)$

According to the TNM system the micrometastases are designated with the index (mi) and their presence places the disease in IIIrd stage, determining the relevant treatment and prognosis. $(89,90)$

For the assessment of the lymph status it is obligatory to investigate morphologically at least 12 lymph nodes. $(85,93)$ If lymph metastases are not detected, it is advisable to search for micrometastases (MM)

A great number of authors in the literature suggest that the presence of $\mathrm{MM}$ is a poor prognostic factor and therefore, are indicating the administration of adjuvant therapy which would improve the prognosis in these "problem" $30 \%$ of the patients "without metastases". The prognostic value of the metastases in CRC requires further investigations in the future. In their studies a number of authors confirm the prognostic value of MM $(49-52,86,87)$, others aren't support this suggestion. $(53-55,88)$

If the all LNs are to be investigated, the methods for micrometastases detection are costly, labor and time consuming. $(85,67,89)$

\section{METHODOLOGY}

We performed intraoperative sentinel mapping for a period of one year (2004-05) in 103 patients operated for colon or 
rectal cancer. An algorithm was worked out for sentinel mapping in colorectal cancer. (Figure 7.) The dying method with Patent Blue V was used.

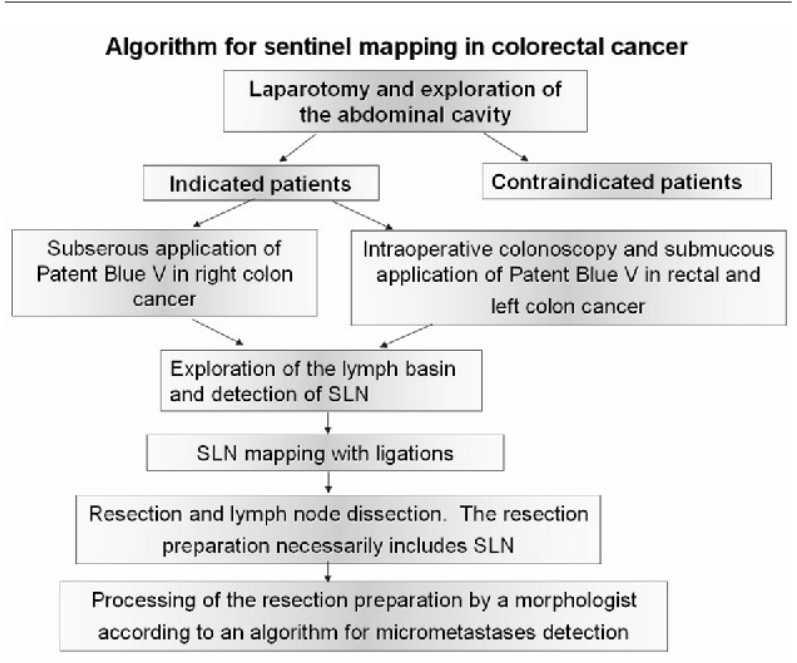

Figure 7. MORPHOLOGICAL INVESTIGATIONS

The SLN tagged by the surgeon are sent to the morphological laboratory together with the resection.

- Routine processing to a paraffin block

- 10 resections in every $20-25 \mu \mathrm{m}$

- Immunohistochemistry with cytokeratin 20 per 1 resection (usually the $5^{\text {th }}$ one)

- The remaining resections together with the preparations from the case are dyed with Hematoxilin - Eosin

Micrometastases - a focus of tumor cells sized under $2 \mathrm{~mm}$ or a focus detected only by means of immunohistochemistry.

\section{Indications:}

- Patients with invasive colorectal cancer;

- Histological diagnosis and preoperative staging performed not later than 3 months before the surgery;

- Life expectancy over 5 years (age up to 80 years);

- Class after ASA I-III.

\section{Contraindications:}

- Presence of distant metastases;

- Preceding local excision of the primary tumor;

- Metachronic colorectal cancer (with some exceptions);

- Recurrent colorectal cancer;

- Presence of cancer in another organ localization during the past 5 years, especially in the cases when the colorectal cancer is difficult to be differentiated histologically;

- Preceding surgical interventions affecting the anatomy of the lymph basin;

- Complicated colorectal cancer (emergency operation);

- Class after ASA IV-V.

After the laparotomy and the abdominal cavity exploration, in the absence of distant metastases and lack of palpatory data for the presence of lymph metastases in patients with cancer of the rectum and the left colon, we performed intraoperative colonoscopy.
By means of an endoscopic injector submucosally we applied 0,5-2 cc Patent Blue V on 2 to 4 locations peritumorally.

Since in right colon cancer the intraoperative colonoscopy up to the caecum is technically difficult to perform and is time-consuming, in these tumor localizations we injected the dye subserously by means of a needle and a syringe $0,5-2 \mathrm{cc}$ on 2 to 4 locations peritumorally.

In 1 to 10 minutes' time the blue-dyed lymph node (s) are visualized connecting the primary tumor with blue-dyed sentinel lymph node(s).

We assume the first 1-4 blue-dyed lymph nodes to be sentinel and we mark them with ligations. It is important that the procedure is performed technically accurately and precisely timed since the dye gradually colours the whole lymph basin and the SLN can lose their colour with time.

According to the tumor localization we perform thorough exploration of the regional lymph basin, the whole mesacolon, the stem of the mesenterial vessels and paraaortally, the obturated fossae and along the course of the iliac vessels in order to detect SLN and the presence of atypical lymph drainage.

\section{RESULTS}

Patients' distribution is shown on Table 1.

Table 1.

\begin{tabular}{l|c|c}
\cline { 2 - 3 } & Colon Cancer & Rectal Cancer \\
\hline Patients & 48 & 55 \\
\hline Male & $22(46 \%)$ & $25(45 \%)$ \\
\hline Female & $26(54 \%)$ & $30(55 \%)$ \\
\hline Average age (years) & 63 & 66 \\
\hline
\end{tabular}

The mean number of the lymph nodes in the resection preparation is 14.7 in cancer of the colon vs. 13.2 in cancer of the rectum.

Table 2.

\begin{tabular}{l|c|c|}
\cline { 2 - 3 } & Colon cancer & Rectal cancer \\
\cline { 2 - 3 } & $\mathbf{n}(\%)$ & $\mathbf{n}(\%)$ \\
\hline Patients & 48 & 55 \\
\hline Successful mapping & $48(100)$ & $55(100)$ \\
\hline $\begin{array}{l}\text { Presence of lymph node } \\
\text { metastases }\end{array}$ & $24(50)$ & $27(49)$ \\
\hline False negative rate & $0(0)$ & $3(5)$ \\
\hline Metastases only in SLN & $8(17)$ & $9(16)$ \\
\hline Detected MM & $5(19)$ & $6(21)$ \\
\hline
\end{tabular}

The mean number of SLN in cancer of the colon is $1.9 \mathrm{vs}$. 1.6 in cancer of the rectum.

One, two, three and four SLN were detected in $40 \%, 39 \%$, $19 \%$ и $2 \%$ of the patients, respectively. 
Metastases were detected in 57\% of the SLN (105 out of 184 ) as compared to $9 \%$ metastases incidence in the nonsentinel LN (198 out of 2208).

In the absence of metastases in SLN the likelihood for metastases occurrence in the nonsentinel LN is only $0,6 \%$ (4 out of 657 nonsentinel LN). (Table 2.)

False negative results were reported when in the presence of metastases, they were not detected in the SLN. We observed false negative results in 3 patients. All of them had large T4 tumors infiltrating in adjacent organs. Therefore, we suggest that such patients are relatively contraindicated for sentinel mapping. We performed mapping in such patients only in the first 24 cases.

In most cases the SLN were located in proximity to the primary tumor. In spite of this we detected a presence of atypical lymph drainage with positive SLN outside the limits of the standard resection in $10(10 \%)$ of the patients.

In 3 out of these 10 patients the aberrant SLN were the only site of lymph metastases.

In 5 patients we performed extended right hemicolectomy with the inclusion of the lineal flexure and its mesocolon because we detected SLN in the region of the flexure.

We extended the size of the lymph dissection in 5 patients with rectal cancer:

- In one of them we detected SLN in the root of a.

mesenterica inferior, which necessitated its high ligation with additional dissection around the root.

- In the remaining 4 we detected SLN in the left or right iliac region and we performed lateral lymph node dissection.

In the rest of the cases when no SLN or enlarged lymph nodes were detected in the lateral ligaments, obtutarated fossae or parailiacally, we did not consider appropriate to perform lateral lymph node dissection in patients with rectal cancer.

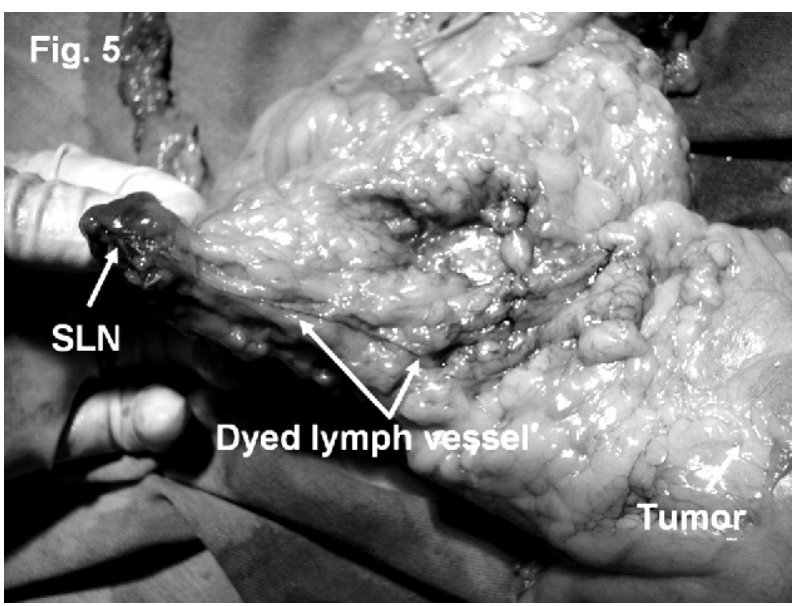

Figure 5.

On Figure 5, it is shown the visualisation of direct lymph drainage from cancer of the rectum T2 to SLN from the IIIrd level in the root of arteria mesenterica inferior. In the same patient the morphological investigation did not reveal metastases in any of the LN in the surgical preparation. The immunohistochemical study of the only SLN revealed MM, e.g. skip metastasing.

On Figure 6, it is shown a case with rectal cancer T3, in whom SLN is positive in the right iliac fossa

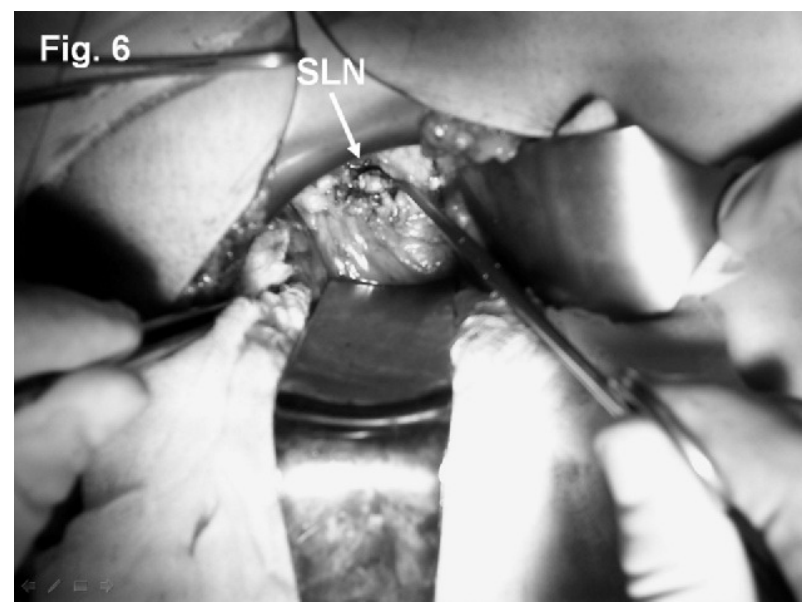

The relation between the $\mathrm{T}$ stage of the primary tumor and the presence of lymph metastases after sentinel mapping is shown on Table 3.

Table 3.

\begin{tabular}{l|c|c|c}
\cline { 2 - 4 } & $T \times, 1,2$ & $T 3$ & $T 4$ \\
\cline { 2 - 4 } & $n(\%)$ & $n(\%)$ & $n(\%)$ \\
\hline Patients & $48(47)$ & $44(43)$ & $11(10)$ \\
\hline $\begin{array}{l}\text { Presence of lymph } \\
\text { node metastases }\end{array}$ & $9(19)$ & $40(90)$ & $11(100)$ \\
\hline Micrometastases & $7(15)$ & $3(7)$ & $0(0)$ \\
\hline
\end{tabular}

\section{DISCUSSION}

- The sentinel mapping in CRC facilitates the detection of atypical lymph drainage of the primary tumor

- Since the SLN have the highest metastatic potential, they should be included in the resection preparation through adequate extension of the size of the lymph dissection, when necessary.

- The detection of MM in SLN reveals the exact status of the whole lymph basin, the correct staging of the disease and serves as a prognostic factor facilitating the appropriate treatment.

- By means of this method the lymph nodes with greatest metastatic potential can be detected, removed and investigated even if they are of very tiny sizes of up to $2-3 \mathrm{~mm}$

- MM are more frequently detected in the lower T-stage of the primary tumor.

We conclude that SLN mapping in colorectal cancer is a convenient diagnostic method for the surgeon allowing him/her for an individualized approach to every single patient. Further studies are needed to validate if routine use of this method will increase the survival of patients operated for colorectal cancer. 


\section{REFFERENCES}

1. Saha, S; Dan, AG.; Bilchik, A; Kitagawa,; Schochet, E; Choudhri, Sh; Saha, L; Wiese, D; Morton, D; Kitajima, M. Historical Review of Lymphatic Mapping in Gastrointestinal Malignancies Ann Surg Oncol Volume 11(3) Supplement March 2004 pp 245S-249S

2. Gould EA, Winship T, Philbin PH, et al. Observations on a "sentinel node" in cancer of the parotid. Cancer 1960; 13: 77-8.

3. Kett K, Varga G, Lukacs L. Direct lymphography of the breast. Lymphology 1970; 3: 2-12

4. Cabanas RM. An approach for the treatment of penile carcinoma. Cancer 1977; 39: 456-66.

5. Morton DL, Wen DR, Wong JH, et al. Technical details of intraoperative lymphatic mapping for early stage melanoma. Arch Surg 1992; 127: 392-9.

6. Hiroya T, A. Bilchik, S. Saha, R. Turner, D. Wiese, M. Tanaka, Ch. Kuo, He-Jing Wang and D. Hoon c-MET Expression Level in Primary Colon Cancer Clinical Cancer Research Vol. 9, April 2003 1480-1488

7. Bilchik A. J., Saha S., Wiese D., Stonecypher J. A., Wood T. F., Sostrin S., Turner R. R., Wang H. J., Morton D. L., Hoon D. S. B. Molecular staging of early colon cancer on the basis of sentinel node analysis: a multicenter phase II trial.. J. Clin. Oncol., 19: 1128-1136, 2001

8. Taback B, Bilchik AJ, Saha S, Nakayama T, Wiese DA, Turner RR, Kuo CT, Hoon DS. Peptide nucleic acid clamp PCR: a novel K-ras mutation detection assay for colorectal cancer micrometastases in lymph nodes. Int J Cancer. 2004 Sep 1;111(3):409-14.

9. Saha, S.; Bilchik, A.; Wiese, D.; Espinosa, M.; Badin, J.; Ganatra, BK.; Desai, D.; Kaushal, S.; Singh, T.; Arora, M. Ultrastaging of Colorectal Cancer by Sentinel Lymph Node Mapping Technique-A Multicenter Trial Ann Surg Oncol Volume 8(9) Supplement October 2001pp 94S-98S

10. Wood, Thomas F.; Saha, S; Morton, Donald L. MD; Tsioulias, George J. MD, DMSc; Rangel, Decio MD; Hutchinson, William Jr. MD; Foshag, Leland J. MD; Bilchik, Anton J. MD, PhD Validation of Lymphatic Mapping in Colorectal Cancer: In Vivo, Ex Vivo, and Laparoscopic Techniques Ann Surg Oncol Volume 8(2)March 2001 pp 150-157

11. Bertagnolli, M; Miedema, B; Redston, M; Dowell, J; Niedzwiecki, D; Fleshman, J; Bem, J; Mayer, R; Zinner, M; Compton, Carolyn MD, PhD Sentinel Node Staging of Resectable Colon Cancer: Results of a Multicenter Study Ann Surg Oncol Volume 240(4) October 2004 pp 624-630

12. Bertoglio S., S. Sandrucci, P. Percivale, M. Goss, M. Gipponi, L. Moresco, B. Mussa, A. Mussa, Prognostic Value of Sentinel Lymph Node Biopsy in the Pathologic Staging of Colorectal Cancer
Patients Journal of Surgical Oncology 2004; 85 : 166-170

13. K. Dahl, J. Westlin, W. Kraaz, O. Winqvist, L. Bergkvist and M. Thцrn Identification of sentinel nodes in patients with colon cancer European Journal of Surgical Oncology Volume 31, Issue 4, May 2005, Pages 381-385

14. Feig BW, S. Curley, A Lucci, K. Hunt, J. N. Vauthey, PF. Mansfield, K Cleary, St Hamilton, V. Ellisa, M. Brame, D. H. Berger, A caution regarding lymphatic mapping in patients with colon cancer The American Journal of Surgery 182 (2001) 707-712

15. Patten L C., D. H. Berger, M. Rodriguez-Bigas,. P. Mansfield,. Eb. Delpassand, K. R. Cleary, Sh. P. Fagan, St. A. Curley, K. K. Hunt, B. W. Feig, M.D. A Prospective Evaluation of Radiocolloid and Immunohistochemical Staining in Colon Carcinoma Lymphatic Mapping CANCER May 15, 2004 / Volume 100 / Number 10 2104-2109

16. Nieweg, O. E.; Tanis, P. J.; Kroon, B. B. R. The Definition of a Sentinel Node Ann Surg Oncol Volume 8(6) July 2001 pp 538-541

17. Thompson JF, Uren RF. What is a 'sentinel' lymph node? Eur J Surg Oncol 2000; 26: 103-4.

18. Tanis P.J., O.E. Nieweg, A.A. M. Hart and B.B. R. Kroon, The Illusion of the Learning Phase for Lymphatic Mapping Annals of Surgical Oncology 9:142-147 (2002)

19. Nieweg, O. E.; Estourgie, S. H. What is a Sentinel Node and What is a False-Negative Sentinel Node? Ann Surg Oncol Volume 11(3) Supplement March 2004 pp 169S-173S

20. Ota D. M., Is Intraoperative Lymph Node Mapping and Sentinel Lymph Node Biopsy for Colorectal Carcinoma Necessary? Annals of Surgical Oncology, 7(2):82-84

21. Saha S, Weise D, Badin J, et al. Technical details of sentinel lymph node mapping in colorectal cancer and its impact on staging. Ann Surg Oncol 2000;7:120-4.

22. Paramo JC., J. Summerall, Ch Wilson, A. Cabral, I. Willis, H. Wodnicki, R. Poppiti,Th. W. Mesko, M.D Intraoperative sentinel lymph node mapping in patients with colon cancer The American Journal of Surgery 182 (2001) 40-43

23. Reintgen D, Cruse CW, Wells K, et al. The orderly progression of melanoma nodal metastases. Ann Surg 1994; 220: 759-67.

24. Morton DL, Chan AD. The concept of sentinel node localization: how it started. Semin Nucl Med 2000; 30: 4-10.

25. Doekhie F.S., K.C.M.J. Peeters, P.J.K. Kuppen, W.E. Mesker, H.J. Tanke, H. Morreau, C.J.H. van de Velde, R.A.E.M. Tollenaar, The feasibility and reliability of sentinel node mapping in colorectal cancer EJSO (2005) 31, 854-862

26. Kitagawa Y., M. Watanabe, H. Hasegawa, S. Yamamoto, H. Fujii, K. Yamamoto, J. Matsuda, M. Mukai, A. Kubo, M Kitajima, Sentinel Node Mapping for Colorectal Cancer With 
Radioactive Tracer Dis Colon Rectum, Vol. 45, No. 11 1476- 1480

27. Trocha SD, Nora DT, Saha SS, Morton DL, Wiese D, Bilchik AJ. Combination probe and dye-directed lymphatic mapping detects micrometastases in early colorectal cancer. $J$ Gastrointest Surg. 2003 Mar-Apr;7(3):340-5; discussion 345-6.

28. Saha S., K. M. Monson, A. Bilchik, Th. Beutler, AG. Dan, E. Schochet, D. Wiese, S. Kaushal, B. Ganatra, D. Desai Comparative Analysis of Nodal Upstaging Between Colon and Rectal Cancers by Sentinel Lymph Node Mapping: A Prospective Trial The American Society of Colon and Rectal Surgeons 2004.10.1007/ s10350-004-0661-5

29. Wood, TF, Tsioulias, GJ, Morton, DL "Focused examination of sentinel lymph nodes upstages early colorectal carcinoma" Am Surg 66: 998-1003

30. Greenlee RT, Murray T, Bolden S, Wingo PA. Cancer statistics, 2000. CA Cancer J Clin 2000; 50: 7-33.

31. Jemal A, Tiwari RC, Murray T. Cancer statistics, 2004. CA Cancer J Clin. 2004;54:8-29.

32. Herrera-Ornelas L: Metastasis in small lymph nodes from colon cancer. Arch Surg 1987; 122: $1253-1256$.

33. Joosten JJ, Strobbe LJ, Wauters CA, et al.: Intraoperative lymphatic mapping and the sentinel node concept in colorectal carcinoma. Br J Surg 1999;86:482-486.

34. Deans G.T., T.G. Parks, B.J. Rowlands and R.A.J. Spence, Prognostic factors in colorectal cancer, Br J Surg 79 (1992), pp. 608-613.

35. Bilchik A.J., D. Nora, R.A.E.M. Tollenaar, C.J.H. van de Velde, T. Wood, R. Turner, D.L. Morton, D.S.B. Hoon Ultrastaging of early colon cancer using lymphatic mapping and molecular analysis European Journal of Cancer 38 (2002) 977-985

36. Fielding P. Staging systems. In Cohen A, Winawer $\mathrm{S}$, eds. Cancer of the Colon, Rectum and Anus. New York, McGraw-Hill, 1995, 207.

37. Bilchik AJ, Giuliano A, Essner R, Bostick P, Kelemen P, Foshag LJ, Sostrin S, Turner RR, Morton DL. Universal application of intraoperative lymphatic mapping and sentinel lymphadenectomy in solid neoplasms. Cancer J Sci Am. 1998 Nov-Dec;4(6):351-8

38. O’Connell MJ, Mailliard JA, Kahn MJ, Controlled trial of fluorouracil and low-dose lecucovorin given for 6 months as postoperative adjuvant therapy for colon cancer. J Clin Oncol 1997, 15, 246-250.

39. Feezor, R. J. MD; Copeland, Edward M. III MD; Hochwald, Steven N. MDSignificance of Micrometastases in Colorectal Cancer Ann Surg Oncol Volume 9(10) December 2002 pp 944-953

40. Saha S, Nora D, Wong JH, Weise D. Sentinel lymph node mapping in colorectal cancer-a review. Surg Clin North Am 2000; 80: 1811-9.

41. Krag DN, Weaver DL, Alex JC,. Surgical resection and radiolocalization of the sentinel node in breast cancer using a gamma probe. Surg Oncol 1993; 2: 335-9.
42. Saha S, Ganatra BK, Gauthier J, Localization of sentinel lymph node in colon cancer. A feasibility study. SSO $50^{\text {th }}$ Annual Cancer Symposium 1997; 80: 54.

43. Kitagawa Y, Fujii H, Mukai M, Current Status and Future Perspectives of Sentinel Node Navigation for Gastrointestinal Cancer. Proceedings of the $3^{\text {rd }}$ International Sentinel Lymph Node Congress 2002;2:136

44. Bilchik AJ, Saha S, Tsioulias GJ, Aberrant drainage and missed micrometastases: the value of lymphatic mapping and focused analysis of sentinel lymph nodes in gastrointestinal neoplasms. Ann Surg Oncol 2001; 8: 82-5S.

45. Ouriel K, Adams JT Adenocarcinoma of the small intestine. Am J Surg. 1984 Jan;147(1):66-71

46. Shiu MH, Perrotti M, Brennan MF Adenocarcinoma of the stomach: a multivariate analysis of clinical, pathologic and treatment factors. Hepatogastroenterology. $1989 \mathrm{Feb} ; 36(1): 7-12$

47. Yeo CJ, Cameron JL, Lillemoe KD, Sitzmann JV, Hruban RH, Goodman SN, Dooley WC, Coleman J, Pitt HA Pancreaticoduodenectomy for cancer of the head of the pancreas. 201 patients. Ann Surg. 1995 Jun;221(6):721-31; discussion 731-3

48. Broll, R, Schauer, V, Schimmelpenning, H "Prognostic relevance of occult tumor cells in lymph nodes of colorectal carcinomas: an immunohistochemical study" Dis Colon Rectum 40: 1465-71

49. Greenson, JK, Isenhart, CE, Rice, R, Mojzisik, C, Houchens, D, Martin, EW, Jr "Identification of occult micrometastases in pericolic lymph nodes of Dukes B colorectal cancer patients using monoclonal antibodies against cytokeratin and CC49. Correlation with long-term survival" Cancer 73: $563-9$

50. Isaka, N, Nozue, M, Doy, M, Fukao, K (1999) "Prognostic significance of perirectal lymph node micrometastases in Dukes B rectal carcinoma: an immunohistochemical study by CAM5.2" Clin Cancer Res 5: 2065-8

51. Palma, RT, Waisberg, J, Bromberg, SH, Simao, AB, Godoy, AC (2003) "Micrometastasis in regional lymph nodes of extirpated colorectal carcinoma: immunohistochemical study using anti-cytokeratin antibodies AE1/AE3" Colorectal Dis 5: $164-8$

52. Adell, G, Boeryd, B, Franlund, B, Sjodahl, R, Hakansson, L (1996) "Occurrence and prognostic importance of micrometastases in regional lymph nodes in Dukes B colorectal carcinoma: an immunohistochemical study" Eur J Surg 162: 637-42

53. Choi, HJ, Choi, YY, Hong, SH "Incidence and prognostic implications of isolated tumor cells in lymph nodes from patients with Dukes B colorectal carcinoma" Dis Colon Rectum 45: 750-5

54. Cutait, R, Alves, VA, Lopes, LC "Restaging of colorectal cancer based on the identification of lymph node micrometastases through immunoperoxidase staining of CEA and cytokeratins" Dis Colon Rectum 34: $917-20$ 
55. Chapuis, PH, Dent, OF, Fisher, R “A multivariate analysis of clinical and pathological variables in prognosis after resection of large bowel cancer" Br J Surg 72: 698-702

56. Lindmark, G, Gerdin, B, Pahlman, L, Bergstrom, R, Glimelius, B (1994) "Prognostic predictors in colorectal cancer" Dis Colon Rectum 37: 1219-27

57. Wiggers, T, Arends, JW, Schutte, B, Volovics, L, Bosman, FT “A multivariate analysis of pathologic prognostic indicators in large bowel cancer" Cancer 61: 386-95

58. Philips RKS, Hittinger R, Blesovsky L, Large bowel cancer: Surgical pathology and its relationship to survival. Br J Surg 1984; 71:604-610.

59. Herrera-Ornelas L: Metastasis in small lymph nodes from colon cancer. Arch Surg 1987;122:1253-1256.

60. Giuliano AE, Kirgan DM, Guenter JM. Lymphatic mappingand sentinel lymphadenectomy for breast cancer. Ann Surg 1994; 3:391-401.

61. Hayashi N, Ito I, Yanagisawa A, et al. Genetic diagnosis of lymph-node metastasis in colorectal cancer. Lancet 1995;345:1257-9.

62. Merrie A.E. H., L.V. Phillips, K. Yun, J. McCall, Skip metastases in colon cancer: Assessment by lymph node mapping using molecular detection Surgery Volume 129, Number 6 2001684-691

63. Tang R, Wang JY, Chen JS, Survival impact of lymph node metastasis in TNM stage III carcinoma of the colon and rectum. J Am Coll Surg 1995;180: 705-12.

64. Ota D. M., Is Intraoperative Lymph Node Mapping and Sentinel LymphNode Biopsy for Colorectal Carcinoma Necessary? Annals of Surgical Oncology, 7(2):82-84

65. Cohen AM, Kelsen D, Saltz L, Adjuvant therapy for colorectal cancer. Curr Prob Cancer 1998;22:565 .

66. Tsioulias G, Wood T, Morton D, Lymphatic mapping and focused analysis of sentinel lymph nodes upstage gastrointestinal neoplasms. Arch Surg 2000; 135: 926-32.

67. Tsioulias GJ, Wood TF, Spirt M, Morton DL, Bilchik AJ. A novel lymphatic mapping technique to improve localization and staging of early colon cancer during laparoscopic colectomy. Am Surg. 2002 Jul;68(7):561-5.

68. Wood TF, Nora DT, Morton DL, Turner RR, Rangel D, Hutchinson W, Bilchik AJ. One hundred consecutive cases of sentinel lymph node mapping in early colorectal carcinoma: detection of missed micrometastases. J Gastrointest Surg. 2002 May-Jun;6(3):322-9; discussion 229-30.

69. Bilchik A.J., D.T. Nora, Lymphatic Mapping of Nodal Micrometastasis in Colon Cancer: Putting the Cart Before the Horse? Annals of Surgical Oncology 9: 529-531 (2002)

70. Bilchik, A., More (Nodes) + More(Analysis $)=$ Less (Mortality): Challenging the Therapeutic Equation for Early-Stage Colon Cancer Annals of Surgical Oncology Volume 10(3) April 2003 pp 203-205
71. Kitagawa Y., M. Kitajima, Gastrointestinal cancer and sentinel node navigation surgery, J. Surg. Oncol. 2002; 79:188-193

72. Kitajima, M., Kitagawa, Y. Universal Applications of Sentinel Node Technology Annals of Surgical Oncology Volume 11(3) Supplement March 2004 pp 144S 146S

73. Kitagawa Y, Fujii H, Mukai M, Kubota T, Ando N, Watanabe M, Ohgami M, Otani Y, Ozawa S, Hasegawa H, Furukawa T, Kumai K, Ikeda T, Nakahara T, Kubo A, Kitajima M The role of the sentinel lymph node in gastrointestinal cancer. Surg Clin North Am. 2000 Dec; 80(6): 1799-809

74. Fujii H, Kitagawa Y, Kitajima M, Kubo A Sentinel nodes of malignancies originating in the alimentary tract. Ann Nucl Med. 2004 Feb;18(1):1-12

75. Morton, D. Sentinel Node Mapping and an International Sentinel Node Society: Current Issues and Future Directions Annals of Surgical Oncology Volume 11(3) Supplement March 2004 pp 137S-142S

76. Bembenek, A., W Haensch, U. Schneider, J. Markwardt, PM Schlag Immunohistochemical detection of lymph-node metastases The Lancet Volume 355, Issue 9198, 8 January 2000, Pages 144-145

77. Dimitrov V., T. Delijski, Lymph Node Dissection in anorectal and intestinal tumors. In: Lymph node dissection in breast, gastrointestinal and urogenital carcinomas. Pleven, 2003

78. Macintosh, E., Colorectal carcinoma. In: Cancer patients follow-up by F. Johnson and R. Virgo. St. Louis, Mosby-Year Book, 1997, 118-47

79. Makela, J., H. Kiviniemi: Survival after operation for colorectal cancer. Eur. J Surg. 2000.

80. Делийски Т. Биопсия на сентинелни лимфни възли при колоректален карцином. В: Биопсия на сентинелни лимфни възли. Плевен, 2004

81. Morson BC, Vaughon, EG, Bussey HIR, 1963, Pelvic recurrence after excision of rectum for carcinoma. BMJ:2:13-17.

82. Pietra, N., L. Sarli et al. Role of follow-up in management of local recurrence of colorectal cancer. Dis. Colon Rectum, 1998,41 10 1127-33

83. Williams, N., S., Surgical Treatment in Rectal Cancer. In: Surgery of the Anus, rectum and colon, $W B$ Saunders,939

84. Martinez S.R, A.J. Bilchik Quality control issues in the management of colon cancer patients Eur $J$ Surg Oncol. 2005 Aug;31(6):616-29

85. Yasuda K, Adachi Y, Shiraishi N, Yamaguchi K, Hirabayashi Y, Kitano S. Pattern of lymph node micrometastasis and prognosis of patients with colorectal cancer. Ann Surg Oncol 2001;8:300-4.

86. Liefers GJ, Cleton-Jansen AM, van de Velde CJ, Hermans J, van Krieken JH, Cornelisse $\mathrm{CJ}$, Micrometastases and survival in stage II colorectal cancer. N Engl J Med 1998;339:223-8.

87. Oberg A, Stenling R, Tavelin B, Lindmark G. Are lymph node micrometastases of any clinical significance in Dukes stages A and B colorectal cancer? Dis Colon Rectum 1998;41: 1244-9.

88. Bilchik AJ, Nora DT, Sobin LH, Turner RR, Trocha S, Krasne D, Effect of lymphatic mapping 
on the new tumor-nodemetastasis classification for colorectal cancer. J Clin Oncol 2003;21:668-72.

89. Sobin LH, Wittekind C (eds): TNM Classification of Malignant Tumors (ed 6). New York: Wiley, 2002

90. Cohen AM, Kelsen D, Saltz L, Minsky BD, Nelson H, Farouk R, et al. Adjuvant therapy for colorectal cancer. Curr Probl Cancer 1998;22:5-65.

91. Wong JH, Bowles BJ, Bueno R, Shimizu D. Impact of the number of negative nodes on disease free survival in colorectal cancer patients. Dis Colon Rectum 2002;45: 1341-8.

92. Rodriguez-Bigas MA, Maamoun S, Weber TK, Penetrante RB, Blumenson LE, Petrelli NJ. Clinical significance of colorectal cancer: metastases in lymph nodes $5 \mathrm{~mm}$ in size. Ann Surg Oncol 1996;3:124-30.
93. Димитров, В. Онкология 2001, 2000,

94. Wolmark N, Fisher B, Wieand HS. The prognostic value of the modifications of the Dukes' $\mathrm{C}$ class of colorectal cancer. An analysis of the NSABP clinical trials. Ann Surg 1986;203: 115-22.

95. P.M. Schlag, A. Bembenek, T. Schulze Sentinel node biopsy in gastrointestinal-tract cancer European Journal of Cancer 40 (2004) 2022-2032

96. Haboubi NY, Clark P, Kaftan SM, The importance of combining xylene clearance and immunohistochemistry in the accurate staging of colorectal carcinoma. J Royal Soc Med 1992; 85: 386-8.

97. Paramo JC., MD, J. Summerall, MD, R. Poppiti, Th. W. Mesko, Validation of Sentinel Node Mapping in Patients With Colon Cancer Annals of Surgical Oncology 9:550-554 (2002) 